\title{
The Net Balance of Acid in Subjects Given Large Loads of Acid or Alkali *
}

\author{
Jacob Lemann, Jr., $\dagger$ Edward J. Lennon, A. David Goodman, John R. \\ Litzow, and Arnold S. Relman $\ddagger$ \\ (From the Evans Memorial Department of Clinical Research, Massachusetts Memorial Hos- \\ pitals, and the Department of Medicine, Boston University Medical Center, Boston, \\ Mass., and the Department of Medicine, Marquette University School of \\ Medicine, Milwaukee, Wis.)
}

It was demonstrated in the preceding paper (2) that patients with severe chronic renal acidosis may excrete significantly less acid in their urine than is released endogenously by metabolic processes. Despite this apparent positive net balance of acid, such patients maintained a steady, although low, level of plasma bicarbonate. After the acidosis had been corrected and plasma bicarbonate maintained at normal levels by the daily administration of sodium bicarbonate, the apparent retention of fixed acid disappeared. It was concluded that severe acidosis per se calls into play some mechanism that helps to stabilize the extracellular bicarbonate level by disposing of that part of the endogenous acid load not excreted in the urine.

In the present work we present studies of the net external acid balance in normal subjects made severely acidotic with ammonium chloride, and we demonstrate that the same mechanism is operative even when there is no renal disease. In addition, balance studies in normal subjects given large loads of sodium bicarbonate are described.

* Submitted for publication September 1, 1964; accepted December 1, 1964.

Presented in part before the Association of American Physicians, May 1964. A preliminary report of some of this work is in press (1).

This investigation was supported in part by a U. S. Public Health Service research career program award (K6-AM-1589) and a research grant (AM-06728) from the National Institute of Arthritis and Metabolic Diseases and by a clinical research center grant (5-MO1FR-58) from the Division of Research Facilities and Resources, National Institutes of Health.

$\dagger$ Present address: Milwaukee County General Hospital, Milwaukee 13, Wis.

$¥$ Address requests for reprints to: Dr. Arnold S. Relman, Boston University Medical Center, 750 Harrison Ave., Boston, Mass. 02118.
These indicate that a portion of excessive alkali loads can also be handled by extrarenal processes in such a manner as to stabilize the plasma bicarbonate level despite an apparent continuously positive balance of alkali or, in other words, a negative net balance of acid. In the absence of any evidence that fecal excretion of acid or base plays an important role in these experiments, it is suggested that the results are best explained by postulating that excess acid or base can be stored in tissue reservoirs or neutralized by buffers fixed in tissues.

\section{Methods}

Eighteen balance studies were carried out, using as volunteer subjects 14 healthy adult males.

Acid loads. Acidosis was gradually induced in five subjects by progressively increasing daily doses of ammonium chloride given over a period of 10 or more days while the subject ate a normal diet. When the serum $\mathrm{CO}_{2}$ content had fallen to 21 mmoles per $\mathrm{L}$ or below, the daily dose of ammonium chloride was held constant (160 to 280 mmoles per day in individual subjects) and a special liquid formula diet substituted (see below). After 2 or more days of adaptation, balance measurements were begun and continued for 4 to 8 days. The ammonium chloride was weighed with an analytical balance and given in gelatin capsules in equal doses at 8:00 a.m., 12:00 noon, 5:00 p.m., and 9:00 p.m. on each day. All subjects tolerated the ammonium chloride fairly well, but often noted fatigue, exertional dyspnea, and anorexia. No subject vomited or was unable to take the prescribed diet. Three of the five subjects remained on a metabolic ward during the study, but the other two carried on their normal activities as medical students. Stools were formed and very small, and contained almost no chloride $(<2 \mathrm{mEq}$ per day), thus indicating complete absorption of the ammonium chloride load.

Alkali loads. Three different protocols were followed in the studies of the effects of sodium bicarbonate loads. 1) Four "recovery" experiments were conducted, as follows. Subjects were allowed to adapt for 2 or more days to the liquid formula diet, to which a fixed amount 
TABLE I

Experimental data: subject R.P., age 35, male; stable acidosis

\begin{tabular}{|c|c|c|c|c|c|c|c|c|c|c|c|c|c|}
\hline \multirow[b]{3}{*}{ Day } & \multirow{3}{*}{$\begin{array}{c}\text { Body } \\
\text { weight }\end{array}$} & \multirow{3}{*}{$\begin{array}{l}\text { Venous } \\
\text { blood } \\
\text { pH }\end{array}$} & \multirow{2}{*}{\multicolumn{4}{|c|}{ Serum }} & \multicolumn{6}{|c|}{ Urine } & \multirow{3}{*}{$\begin{array}{l}\text { Endog- } \\
\text { enous } \\
\text { acid } \\
\text { produc- } \\
\text { tion§ } 8\end{array}$} \\
\hline & & & & & & & & & & Net & Inor- & & \\
\hline & & & $\mathrm{CO}_{2}$ & $\mathrm{Na}$ & $\mathbf{K}$ & $\mathrm{Cl}$ & $\mathrm{pH}$ & T.A. $\dagger$ & $\mathrm{NH}_{4}$ & tionf & $\mathrm{SO}_{4}$ & acids & \\
\hline \multicolumn{3}{|c|}{$k g$} & mmoles $/ L$ & \multicolumn{3}{|c|}{$m E q / L$} & \multicolumn{6}{|c|}{$m E q / d a y$} & $\underset{d a y}{m E q /}$ \\
\hline 1 & 76.01 & 7.25 & 17.0 & & & & 5.38 & 32 & 256 & 288 & 38 & 45 & 83 \\
\hline 2 & 75.25 & 7.25 & 16.2 & 138 & 3.7 & 115 & 5.38 & 30 & 274 & 304 & 38 & 47 & 85 \\
\hline 3 & 75.15 & 7.25 & 15.3 & & & 114 & 5.43 & 30 & 281 & 311 & 35 & 49 & 84 \\
\hline 4 & 75.35 & 7.27 & 13.6 & & & 113 & 5.42 & 31 & 305 & 336 & 33 & 52 & 85 \\
\hline 5 & 75.25 & 7.28 & 15.5 & 136 & 3.6 & 114 & 5.42 & 30 & 288 & 318 & 33 & 47 & 80 \\
\hline 6 & 74.91 & 7.29 & 17.4 & & & & 5.40 & 28 & 309 & 337 & 34 & 53 & 87 \\
\hline 7 & 75.23 & 7.29 & 17.6 & & & 113 & 5.50 & 25 & 304 & 329 & 35 & 49 & 84 \\
\hline 8 & 75.08 & 7.32 & 18.0 & 138 & 3.5 & 112 & & & & & & & \\
\hline
\end{tabular}

* Intake per day: $\mathrm{Na}, 112 \mathrm{mEq} ; \mathrm{K}, 65 \mathrm{mEq} ; \mathrm{Cl}, 440 \mathrm{mEq}\left(178 \mathrm{mEq}\right.$ in diet plus $262 \mathrm{mEq}$ as $\left.\mathrm{NH}_{4} \mathrm{Cl}\right) ; \mathrm{Ca}, 13.1 \mathrm{mEq} ; \mathrm{P}, 10 \mathrm{mmoles} ;$ and $\mathrm{N}$, $15.9 \mathrm{~g}\left(12.2 \mathrm{~g}\right.$ in diet plus $3.7 \mathrm{~g}$ as $\left.\mathrm{NH}_{4} \mathrm{Cl}\right)$

$\dagger$ Titratable acidity.

Urine $\mathrm{NH}_{4}^{+}$plus T.A. minus $\mathrm{HCO}_{3}^{-}$

Inorganic SO, plus organic acids (see references 3 and 4).

Endogenous acid production plus $\mathrm{NH}_{4} \mathrm{Cl}$ fed.

Total effective acid production minus net acid excretion.

of sodium chloride had been added. Control observations were then made for 5 to 7 days. Constant loads of sodium bicarbonate ( 100 to $150 \mathrm{mEq}$ per day in the individual subjects) were then given for 7 days, by continuing the same sodium intake and substituting bicarbonate for part of the chloride. After stopping the bicarbonate and resuming the previous chloride intake, the balances were continued for an additional 5 to 7 days. 2) Five "acute" studies were performed in which sodium bicarbonate and the liquid formula diet were begun simultaneously, and after 2 or more adaptation days, net acid balance was measured for 7 to 9 days while the subjects continued on the bicarbonate and the special diet. 3) Finally, four "chronic" studies were carried out, in which $150 \mathrm{mEq}$ of sodium bicarbonate was fed daily for periods of 25 to 46 days while the subjects ate their usual diet. The liquid formula diet was then substituted and the bicarbonate continued. After 2 or more adaptation days, balance data were collected for 6 to 8 days.

In all of these experiments, the sodium bicarbonate was accurately weighed with an analytical balance and dispensed in gelatin capsules in 4 equal doses at 8:00 a.m., 12:00 noon, $5: 00$ p.m., and 9:00 p.m. The subjects showed no adverse effects. Stools were infrequent, formed, and contained $<3 \mathrm{mEq}$ of sodium per day, thus suggesting complete absorption of the administered sodium bicarbonate.

The composition of the special liquid formula diet, the analytical methods used, and the methods and principles underlying the calculation of the net external balance of acid have been described previously $(3,4)$. In some of the present studies urinary ammonia was determined by an automated, colorimetric technique (5) after validation of this procedure by comparison with Conway's microdiffusion method (6). Creatinine and phosphorus were determined in all studies with the Technicon autoanalyzer.

\section{Results \\ Ammonium chloride acidosis in normal subjects}

Table I shows the complete balance data for subject R.P., who received $262 \mathrm{mEq}$ of ammonium chloride each day during the 7 days of study.

Body weight decreased $0.93 \mathrm{~kg}$. Venous $\mathrm{pH}$ and serum $\mathrm{CO}_{2}$ content were low and fluctuated slightly, without any suggestion of a downward trend as the study progressed. If anything, these values were slightly higher at the end.

Daily net acid excretion in the urine [titratable acid (T.A.) plus ammonia minus bicarbonate] ranged from 288 to $337 \mathrm{mEq}$ per day. Endogenous acid production varied from 80 to $87 \mathrm{mEq}$ per day, but since the subject received $262 \mathrm{mEq}$ of $\mathrm{NH}_{4} \mathrm{Cl}$ each day, the total effective acid load was 342 to $349 \mathrm{mEq}$ per day. The acid balance was thus positive on each day, varying between +11 and $+57 \mathrm{mEq}$ per day, despite the fact that serum $\mathrm{CO}_{2}$ content did not fall.

Urinary excretion of nitrogen and of various inorganic constituents did not vary greatly. Creatinine excretion (not shown in the Table) was also steady. The stool, as expected, contained substantial amounts of calcium and phosphorus, but negligible quantities of sodium and potassium and no detectable chloride.

Because of the relatively large urinary losses, the average daily balances of potassium $(-11$ $\mathrm{mEq})$, calcium (-42 $\mathrm{mEq})$, and phosphorus 
TABLE I

induced by the administration of $262 \mathrm{mEq} \mathrm{NH}_{4} \mathrm{Cl}$ daily*

\begin{tabular}{|c|c|c|c|c|c|c|c|c|c|c|c|c|c|c|}
\hline \multirow{2}{*}{$\underset{\text { fed }}{\mathrm{NH}_{4} \mathrm{Cl}}$} & \multirow{2}{*}{$\begin{array}{l}\text { Total } \\
\text { effective } \\
\text { acid } \\
\text { produc- } \\
\text { tion\| }\end{array}$} & \multirow{2}{*}{$\underset{\text { balance }}{\text { Acid }}$} & \multicolumn{6}{|c|}{ Urine } & \multicolumn{6}{|c|}{ Stool } \\
\hline & & & $\mathrm{Na}$ & $\mathrm{K}$ & $\mathrm{Ca}$ & $\mathrm{Cl}$ & $\mathbf{P}$ & $\mathbf{N}$ & $\mathrm{Na}$ & $\mathbf{K}$ & $\mathrm{Ca}$ & $\mathrm{Cl}$ & $\mathbf{P}$ & $\mathbf{N}$ \\
\hline$m E q / d a y$ & $m E q / d a y$ & $m E q / d a y$ & \multicolumn{4}{|c|}{$m E q / d a y$} & $\begin{array}{c}\text { mmoles/ } \\
\text { day }\end{array}$ & $g / d a y$ & \multicolumn{4}{|c|}{$m E q / d a y$} & $\begin{array}{c}\text { mmoles/ } \\
\text { day }\end{array}$ & $\begin{array}{l}\text { g/ } \\
\text { day }\end{array}$ \\
\hline 262 & 345 & +57 & 95 & 90 & 25 & 392 & 17 & 17.5 & 2 & 4 & 26 & 0 & 19 & 1.5 \\
\hline 262 & 347 & +43 & 105 & 82 & 29 & 412 & 15 & 18.1 & 2 & 4 & 26 & 0 & 19 & 1.5 \\
\hline 262 & 346 & +35 & 109 & 68 & 29 & 416 & 14 & 17.9 & 2 & 4 & 26 & 0 & 19 & 1.5 \\
\hline 262 & 347 & +11 & 120 & 77 & 28 & 448 & 15 & 18.8 & 2 & 4 & 26 & 0 & 19 & 1.5 \\
\hline 262 & 342 & +24 & 111 & 62 & 28 & 410 & 14 & 18.0 & 2 & 4 & 26 & 0 & 19 & 1.5 \\
\hline 262 & 349 & +12 & 105 & 57 & 31 & 422 & 12 & 18.2 & 2 & 4 & 26 & 0 & 19 & 1.5 \\
\hline 262 & 346 & +17 & 130 & 66 & 32 & 456 & 12 & 16.9 & 2 & 4 & 26 & 0 & 19 & 1.5 \\
\hline
\end{tabular}

(-23 mmoles) were significantly negative as compared to normal subjects receiving the same liquid formula diet without ammonium chloride. Balances of inorganic cations and anions will be discussed in more detail in connection with Table VII, below. Subject R.P. was also in negative nitrogen balance, averaging $-3.4 \mathrm{~g}$ per day.

Figure 1 illustrates the results in another normal subject (J.L.), who received $280 \mathrm{mEq}$ of $\mathrm{NH}_{4} \mathrm{Cl}$ daily during the study. Endogenous acid production is shown as a dotted line plotted downward from the zero line and averaged $81 \mathrm{mEq}$ per day. The ammonium chloride intake is added to this, and the heavy solid line at the bottom thus represents the total effective acid production, which averaged $361 \mathrm{mEq}$ per day. Net acid excretion in the urine (T.A. $+\mathrm{NH}_{4}^{+}-\mathrm{HCO}_{3}^{-}$) is plotted upward from the bottom line and is indicated by the total length of the shaded areas. The clear area below the zero line on each day indicates that there was a continuously positive acid balance, averaging $+28 \mathrm{mEq}$ per day. As can be seen in the Figure, serum $\mathrm{CO}_{2}$ content remained essentially constant, in the range of 19 to 20 mmoles per L. Venous $\mathrm{pH}$ was 7.25 at the beginning of the study and 7.29 at the end. As in the study of subject R.P., negative balances of potassium, calcium, phosphorus, and nitrogen were observed.

Table II summarizes the pertinent data on acid balance in all five studies of ammonium chloride acidosis in normal subjects and compares the mean daily acid balance in this group with that previously found in 27 studies of 18 normal subjects on the same liquid diet who did not take ammonium chloride (3). The mean acid balance was $+24 \pm 9 \mathrm{mEq}$ per day in the five subjects given ammonium chloride, which is significantly more positive than the mean balance of $0 \pm 7$ $\mathrm{mEq}$ per day in the 27 control studies of the normal subjects not made acidotic. Table II also

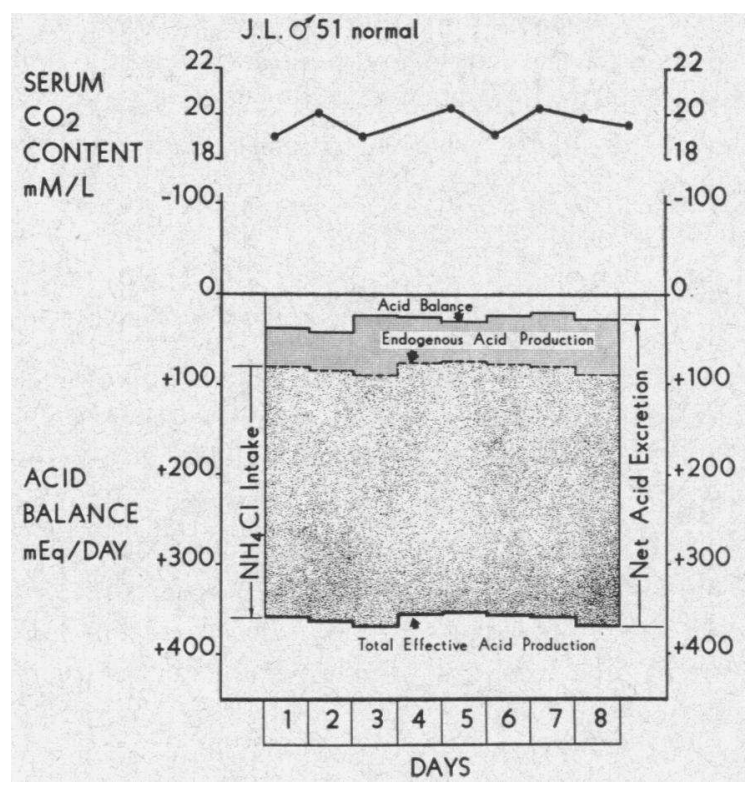

Fig. 1. Acid balance and Serum $\mathrm{CO}_{2}$ CONTENT in A NORMAL SUBJECT GIVEN $280 \mathrm{ME} Q$ of $\mathrm{NH}_{4} \mathrm{Cl}$ daIly. See text for further details. 
TABLE II

Acid balance in five normal subjects with stable $\mathrm{NH}_{4} \mathrm{Cl}$ acidosis

\begin{tabular}{|c|c|c|c|c|c|c|c|c|c|}
\hline \multirow[b]{2}{*}{ Subject } & \multirow[b]{2}{*}{ Days } & \multirow{2}{*}{$\begin{array}{l}\text { Mean daily } \\
\text { endogenous } \\
\text { acid production }\end{array}$} & \multirow{2}{*}{$\begin{array}{l}\text { Daily } \\
\text { NH4Cl } \\
\text { load }\end{array}$} & \multirow{2}{*}{$\begin{array}{l}\text { Mean } \\
\text { daily } \\
\text { total } \\
\text { acid } \\
\text { produc- } \\
\text { tion }\end{array}$} & \multirow{2}{*}{$\begin{array}{l}\text { Mean } \\
\text { daily } \\
\text { net } \\
\text { acid } \\
\text { excretion }\end{array}$} & \multirow{2}{*}{$\begin{array}{l}\text { Mean daily } \\
\text { acid balance }\end{array}$} & \multicolumn{3}{|c|}{ Serum $\mathrm{CO}_{2}$ content } \\
\hline & & & & & & & Initial & Final & Change \\
\hline & & $m E q$ & $m E q$ & $m E q$ & $m E q$ & $m E q$ & & mmoles $/ L$ & \\
\hline P.R. & 4 & 60 & 160 & 220 & 208 & +12 & 18.7 & 19.5 & +0.8 \\
\hline R.R. & 6 & 90 & 243 & 333 & 298 & +35 & 21.0 & 18.7 & -2.3 \\
\hline J.L. & 8 & 81 & 280 & 361 & 333 & +28 & 19.0 & 19.5 & +0.5 \\
\hline R.S. & 8 & 70 & 217 & 287 & 268 & +19 & 16.8 & 18.2 & +1.4 \\
\hline R.P. & 7 & 84 & 262 & 346 & 318 & +28 & 17.0 & 18.0 & +1.0 \\
\hline $\begin{array}{l}\text { Mean of } \\
5 \text { studies } \\
\pm \mathrm{SD}\end{array}$ & & $\begin{array}{c}1.23 \pm 0.18 \\
\mathrm{mEq} / \mathrm{kg} / \text { day }\end{array}$ & & & & $+24 \pm 9$ & $18.5 \pm 1.7$ & $18.8 \pm 0.7$ & $\begin{array}{l}+0.3 \pm 1.5 \\
(\mathrm{p}<0.40)^{*}\end{array}$ \\
\hline $\begin{array}{l}\text { Mean of } 27 \\
\text { studies in } \\
18 \text { normals } \\
\pm \mathrm{SD}\end{array}$ & & $\begin{array}{l}0.93 \pm 0.12 \\
\mathrm{mEq} / \mathrm{kg} / \mathrm{day}\end{array}$ & & & & $0 \pm 7$ & & & \\
\hline $\begin{array}{l}\text { Normal vs. } \\
\text { acid-loaded } \\
\text { subjects }\end{array}$ & & $\mathrm{p}<0.001$ & & & & $\mathrm{p}<0.001$ & & & \\
\hline
\end{tabular}

* Significance of mean change in paired initial and final serum $\mathrm{CO}_{2}$ content.

shows that acidosis did not cause any compensatory reduction in endogenous acid production; there was actually a slightly, but significantly greater endogenous metabolic production of acid in the acidotic group although all subjects were fed exactly the same diet per unit weight. The three right-hand columns of the Table show that despite the large positive balances of acid in the acidotic group there were no significant or consistent changes in serum $\mathrm{CO}_{2}$ content.

\section{Effects of $\mathrm{NaHCO}_{3}$ loads in normal subjects}

1) "Recovery" experiments. The complete balance data for subject K.E.W. are shown in Table III. This subject was studied during a 5-day control period, for 7 days while receiving $150 \mathrm{mEq}$ of $\mathrm{NaHCO}_{3}$ daily, and then for 7 final days after $\mathrm{NaHCO}_{3}$ had been stopped.

In the control period, body weight, serum $\mathrm{CO}_{2}$ content, and venous $\mathrm{pH}$ were stable. The urine was acid, and daily urinary acid excretion ranged from 87 to $99 \mathrm{mEq}$. Daily endogenous acid production varied from 88 to $94 \mathrm{mEq}$. Acid balance varied somewhat, but the average value $(-3 \mathrm{mEq}$ per day) was close to zero for the 5 control days.
During the next 7 days, $150 \mathrm{mEq}$ of $\mathrm{NaHCO}_{3}$ was substituted for an equivalent amount of $\mathrm{NaCl}$ in the control diet. Body weight, venous blood $\mathrm{pH}$, serum $\mathrm{CO}_{2}$ content, and serum electrolytes were essentially unchanged from control measurements. The urine became alkaline. Urinary titratable acid was abolished, ammonia excretion fell, and bicarbonate excretion promptly rose. Bicarbonate excretion exceeded T.A. plus $\mathrm{NH}_{4}{ }^{+}$ on days 7 through 12 , and so net acid excretion was negative, averaging $-38 \mathrm{mEq}$ per day for the period of bicarbonate administration. Endogenous acid production dropped very slightly on the first 2 days of alkali loading, but then returned to control levels; the average for the period was not significantly different from the values during the control period. Because $150 \mathrm{mEq}$ of bicarbonate was fed each day, the average net effective acid production was negative. The effective acid load was usually more negative than urinary acid excretion, and so the acid balance was also negative, averaging $-27 \mathrm{mEq}$ per day. There was, however, considerable variation in the daily balance.

Sodium and potassium excretion in the urine 
were not significantly changed by the alkali load, but chloride was reduced, due to the lowered intake. Fecal excretion of calcium and phosphorus decreased. There was a slight, probably insignificant reduction in fecal potassium. Sodium content of stool remained very low, indicating complete absorption of the sodium bicarbonate.

Bicarbonate was then abruptly stopped on day 13 and chloride resumed for 7 additional days of balance study. Again, body weight, venous blood $\mathrm{pH}$, serum $\mathrm{CO}_{2}$ content, and serum electrolytes remained steady. Urine $\mathrm{pH}$ fell and urinary titratable acid and ammonium gradually returned to control levels. Urinary bicarbonate excretion continued for only 1 day. Endogenous acid production was unchanged. The average daily acid balance was $+18 \mathrm{mEq}$ per day. The urinary excretion of chloride rose again to its previous levels, but otherwise there was no significant change in the excretion of the urine electrolytes. Stool calcium and phosphorus excretion increased again to control levels.

If it is assumed that the mean acid balance during the control period ( $-3 \mathrm{mEq}$ per day) would have continued throughout the entire study if sodium bicarbonate had not been added, the cumulative change in acid balance produced by the bicarbonate load (corrected for control) was $-165 \mathrm{mEq}$, and after the load the balance was $+149 \mathrm{mEq}$ for the 7 recovery days. Thus, most of the acid lost during the alkali-loading period was retained again during the subsequent recovery period.

Table IV shows the results of the 4 "recovery" experiments that followed this protocol. The total $\mathrm{NaHCO}_{3}$ load fed (the sum of the daily $\mathrm{NaHCO}_{3}$ doses) is shown in column A. The total reduction in acid excretion observed from the beginning of the $\mathrm{NaHCO}_{3}$ administration to the end of the recovery period (corrected for the small mean deviations from zero balance noted in the control period of each individual study) is shown in column B. Endogenous acid production was unchanged by the alkali load, so comparison of the total reduction in acid excretion with the amount of alkali fed indicates the extent to which renal adjustments responded to the alkali. When the total reduction in acid excretion is expressed as a per cent of the $\mathrm{HCO}_{3}^{-}$fed (last column), it is

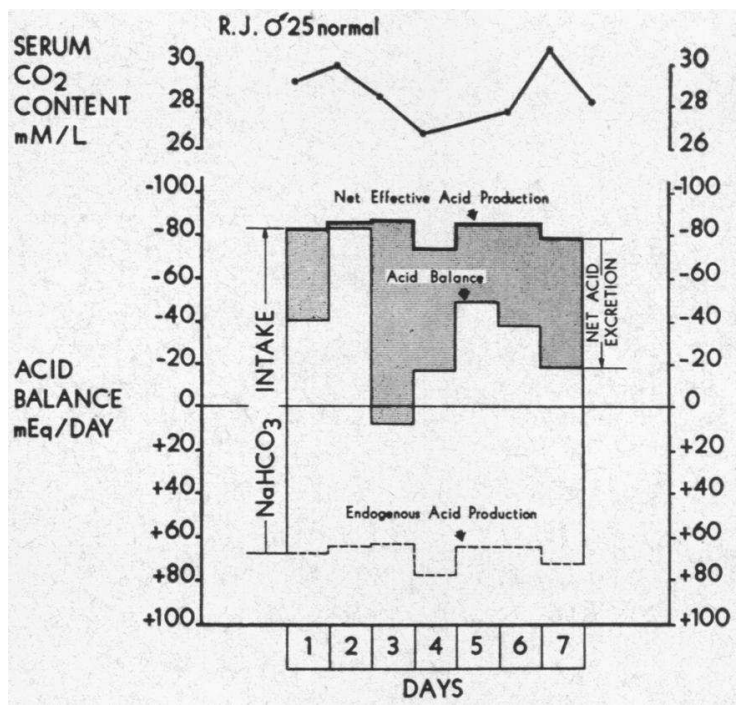

Fig. 2. Acid balance and Serum $\mathrm{CO}_{2}$ COntent in a NORMAL SUBJECT GIVEN $150 \mathrm{ME} Q$ OF $\mathrm{NAHCO}_{3}$ DAILY, ACCORDING to THE "ACUTE" PROTOCOL. See text for further details.

apparent that in three of the studies virtually all of the fed bicarbonate was balanced by reduction in the net renal excretions of acid; in the fourth study (R.R.) only $88 \%$ of the alkali load could be accounted for.

2) "Acute" and "chronic" experiments. Figure 2 illustrates the results of an "acute" study in subject R.J. in which balance data were collected for 7 days beginning 2 days after the liquid formula diet and sodium bicarbonate $(150 \mathrm{mEq}$ per day) were started. In Figure 2, endogenous acid production is plotted downward from the zero line and shown as a light dotted line. The bicarbonate administered is plotted upward from the zero line. The bicarbonate exceeded acid production, and so, as shown by the heavy solid line at the top, the net effective acid production was negative. Furthermore, since urinary bicarbonate excretion exceeded the sum of ammonium plus titratable acid, acid excretion was also negative and is shown as a shaded column extending back towards the zero line, starting from the heavy solid line of net effective acid production. It is apparent from the Figure that acid balance varied considerably but was usually negative (shown by the clear spaces above the zero line), averaging $-34 \mathrm{mEq}$ per day. As shown, serum $\mathrm{CO}_{2}$ con- 
TABLE III

Experimental data: subject K.E.W., age 24,

\begin{tabular}{|c|c|c|c|c|c|c|c|c|c|c|c|c|c|}
\hline \multirow[b]{3}{*}{ Day } & \multirow[b]{3}{*}{$\underset{\text { weight }}{\text { Body }}$} & \multirow[b]{3}{*}{$\underset{\mathrm{pH}}{\text { Blood }}$} & \multirow{2}{*}{\multicolumn{4}{|c|}{ Serum }} & \multicolumn{7}{|c|}{ Urine } \\
\hline & & & & & & & \multirow[b]{2}{*}{$\mathrm{pH}$} & \multirow[b]{2}{*}{$\begin{array}{l}\text { Total } \\
\mathrm{CO}_{2}\end{array}$} & \multirow[b]{2}{*}{ T.A.† } & \multirow[b]{2}{*}{$\mathrm{NH}_{4}$} & \multirow{2}{*}{$\begin{array}{c}\text { Net } \\
\text { acid } \\
\text { excre- } \\
\text { tion† }\end{array}$} & \multirow[b]{2}{*}{$\begin{array}{l}\text { Inorg. } \\
\text { SO. }\end{array}$} & \multirow[b]{2}{*}{$\begin{array}{l}\text { Org. } \\
\text { acids }\end{array}$} \\
\hline & & & $\begin{array}{l}\text { Total } \\
\mathrm{CO}_{2}\end{array}$ & $\mathrm{Na}$ & $\mathbf{K}$ & $\mathrm{Cl}$ & & & & & & & \\
\hline & $k g$ & & mmoles $/ L$ & & $m E q / L$ & & & $\begin{array}{c}\text { mmoles/ } \\
\text { day }\end{array}$ & & & $m E q / d a y$ & & \\
\hline 1 & 102.89 & 7.38 & 28.9 & & & & 5.32 & 0 & 23 & 68 & 91 & 43 & 46 \\
\hline 2 & 102.57 & & & & & & 5.41 & o & 23 & 68 & 91 & 48 & 43 \\
\hline 3 & 102.40 & 7.37 & 29.5 & 138 & 4.2 & 104 & 5.40 & 0 & 18 & 69 & 87 & 48 & 40 \\
\hline 4 & 102.02 & & & & & & 5.30 & 0 & 22 & 76 & 98 & 44 & 45 \\
\hline 5 & 103.24 & 7.32 & 29.0 & & & & 5.35 & 0 & 20 & 79 & 99 & 46 & 48 \\
\hline $6 \|$ & 102.16 & 7.38 & 30.4 & & & & 6.67 & 21 & 4 & 35 & 22 & 39 & 42 \\
\hline $7 \|$ & 101.94 & 7.40 & 29.9 & 138 & 4.0 & 104 & 7.49 & 58 & 0 & 13 & -42 & 43 & 38 \\
\hline $8 \|$ & 102.33 & 7.34 & 28.3 & & & & 7.36 & 36 & 0 & 14 & -20 & 43 & 44 \\
\hline $9 \|$ & 102.94 & & & & & & 7.65 & 63 & -1 & 9 & -53 & 42 & 42 \\
\hline $10 \|$ & 103.42 & 7.33 & 30.5 & & & & 7.49 & 83 & 0 & 11 & -69 & 41 & 47 \\
\hline $11 \|$ & 103.21 & & & & & & 7.46 & 78 & $\mathbf{0}$ & 12 & -62 & 42 & 46 \\
\hline $12 \|$ & 103.00 & 7.38 & 28.9 & 138 & 4.2 & 104 & 7.34 & 57 & 0 & 13 & -41 & 41 & 49 \\
\hline 13 & 102.79 & 7.36 & 32.0 & & & & 6.68 & 35 & 8 & 30 & 10 & 38 & 48 \\
\hline 14 & 101.83 & 7.34 & 31.5 & & & & 5.26 & 0 & 24 & 53 & 77 & 40 & 43 \\
\hline 15 & 102.52 & 7.33 & 30.9 & & & & 5.29 & 0 & 21 & 56 & 77 & 41 & 49 \\
\hline 16 & 102.42 & 7.33 & 28.7 & 140 & 4.1 & 103 & 5.32 & o & 19 & 58 & 77 & 43 & 47 \\
\hline 17 & 102.37 & 7.30 & 26.9 & & & & 5.33 & 0 & 18 & 62 & 80 & 44 & 46 \\
\hline 18 & 102.34 & 7.38 & 27.3 & & & & 5.31 & 0 & 17 & 68 & 85 & 44 & 51 \\
\hline 19 & 102.11 & 7.37 & 29.4 & 138 & 4.0 & 104 & 5.19 & 0 & 19 & 69 & 88 & 42 & 46 \\
\hline 20 & 101.82 & 7.35 & 28.4 & & & & & & & & & & \\
\hline
\end{tabular}

* Intake per day: $\mathrm{K}, 104.8 \mathrm{mEq} ; \mathrm{Ca}, 17.6 \mathrm{mEq} ; \mathrm{Na}, 206 \mathrm{mEq} ; \mathrm{P}, 13.6$ mmoles. Because of reduction in $\mathrm{NaCl}$ intake during $\mathrm{NaHCO}$ feeding the $\mathrm{Cl}$ intake was: days 1 to $5,306 \mathrm{mEq}$; days 6 to $12,156 \mathrm{mEq}$; days 12 to $19,306 \mathrm{mEq}$.

+ See footnotes to Table I for explanation of column headings.

Endogenous acid production minus alkali fed.

Net effective acid production minus net acid excretion.

Net effective acid production minus net
$150 \mathrm{mEq}$ NaHCO, fed on these days.

tent fluctuated between 26 and 31 mmoles per $\mathrm{L}$ without any consistent trend.

Table V summarizes pertinent experimental results in the five "acute" experiments described above and also includes the results of the four "recovery" experiments. Table VI gives comparable data for the four "chronic" studies in which $\mathrm{NaHCO}_{3}$ was fed for prolonged periods ( 25 to 46 days) before the balance was started.

TABLE IV

Comparison of cumulative reduction in net acid excretion with the total alkali load in four normal subjects given NaHCOs according to the "recovery" protocol

\begin{tabular}{lccc}
\hline \hline Subject & $\begin{array}{c}\mathrm{A} \\
\text { Total } \\
\text { NaHCO } \\
\text { load }\end{array}$ & $\begin{array}{c}\text { B } \\
\text { Total } \\
\text { reduction } \\
\text { in acid } \\
\text { excretion* }\end{array}$ & $\begin{array}{c}\text { Per cent of } \\
\text { NaHCOs } \\
\text { accounted for } \\
\text { (B/A X100) }\end{array}$ \\
\hline J.H. & $m E q$ & $m E q$ & $\%$ \\
K.E.W. & 1,050 & 1,061 & 101 \\
H.T. & 1,050 & 1,032 & 98 \\
R.R. & 700 & 702 & 100 \\
& 700 & 612 & 88 \\
& & & Mean $96.8 \%$
\end{tabular}

* Corrected for control acid balance. See text for details.
As both Tables show, in every case the mean net effective acid production (endogenous acid production minus alkali administered) was more negative than the net acid excretion. Hence the acid balance was always negative. In the "acute" and "recovery" experiments of Table V, the acid balance ranged from -4 to $-34 \mathrm{mEq}$ per day, with a mean value of $-20 \pm 9 \mathrm{mEq}$ per day. In the "chronic" experiments the mean value $(-23 \pm 14 \mathrm{mEq}$ per day) and the range ( -3 to $-32 \mathrm{mEq}$ per day) of the acid balance were almost the same. Both mean values were significantly more negative $(p<0.001)$ than the mean acid balance in normal subjects not given alkali (Table II). Despite the relatively large negative balances in the subjects given bicarbonate there were no significant changes in serum $\mathrm{CO}_{2}$ content (Tables V and VI).

Endogenous acid production was not affected by the administration of alkali acutely or chronically. Thus the mean values of $0.89 \pm 0.13 \mathrm{mEq}$ per $\mathrm{kg}$ per day in the subjects of Table $\mathrm{V}$ and of 
TABLE III

male; $\mathrm{NaHCO}$ loading and recovery*

\begin{tabular}{|c|c|c|c|c|c|c|c|c|c|c|c|c|c|}
\hline \multirow{2}{*}{$\begin{array}{l}\text { Endog- } \\
\text { enous } \\
\text { acid } \\
\text { prod. } t\end{array}$} & \multirow{2}{*}{$\underset{\text { fed }}{\text { Alkali }}$} & \multirow{2}{*}{$\begin{array}{l}\text { Net } \\
\text { effec- } \\
\text { tive } \\
\text { acid } \\
\text { prod. }\end{array}$} & \multirow{2}{*}{$\begin{array}{c}\text { Acid } \\
\text { balance }\end{array}$} & \multicolumn{5}{|c|}{ Urine } & \multicolumn{5}{|c|}{ Stool } \\
\hline & & & & $\mathrm{Na}$ & $\mathbf{K}$ & $\mathrm{Ca}$ & $\mathrm{Cl}$ & $\mathbf{P}$ & $\mathrm{Na}$ & $\mathbf{K}$ & $\mathrm{Ca}$ & $\mathrm{Cl}$ & $\mathbf{P}$ \\
\hline$\underset{d a y}{m E q /}$ & $\underset{d a y}{m E q /}$ & $\underset{d a y}{m E q /}$ & $\underset{d a y}{m E q /}$ & \multicolumn{4}{|c|}{$m E q / d a y$} & $\begin{array}{c}\text { mmoles/ } \\
\text { day }\end{array}$ & \multicolumn{4}{|c|}{$m E q / d a y$} & $\underset{\text { day }}{\text { mmoles/ }}$ \\
\hline 89 & 0 & 89 & -2 & 216 & 92 & 7 & 319 & 11 & 1 & 9 & 19 & 1 & 14 \\
\hline 91 & 0 & 91 & 0 & 197 & 78 & 7 & 289 & 10 & 1 & 9 & 19 & 1 & 14 \\
\hline 88 & $\mathbf{0}$ & 88 & +1 & 141 & 75 & 7 & 236 & 4 & 1 & 9 & 19 & 1 & 14 \\
\hline 89 & 0 & 89 & -9 & 170 & 79 & 7 & 282 & 8 & 1 & 9 & 19 & 1 & 14 \\
\hline 94 & 0 & 94 & -5 & 209 & 89 & 7 & 327 & 5 & 1 & 9 & 19 & 1 & 14 \\
\hline 81 & 150 & -69 & -91 & 152 & 78 & 3 & 178 & 5 & 1 & 5 & 11 & 0 & 9 \\
\hline 81 & 150 & -69 & -27 & 151 & 82 & 3 & 104 & 6 & 1 & 5 & 11 & 0 & 9 \\
\hline 87 & 150 & -63 & -43 & 126 & 63 & 3 & 88 & 3 & 1 & 5 & 11 & 0 & 9 \\
\hline 84 & 150 & -66 & -13 & 177 & 83 & 3 & 121 & 5 & 1 & 5 & 11 & 0 & 9 \\
\hline 88 & 150 & -62 & +7 & 190 & 102 & 3 & 138 & 4 & 1 & 5 & 11 & 0 & 9 \\
\hline 88 & 150 & -62 & 0 & 192 & 106 & 3 & 155 & 5 & 1 & 5 & 11 & 0 & 9 \\
\hline 90 & 150 & -60 & -19 & 198 & 88 & 3 & 163 & 5 & 1 & 5 & 11 & 0 & 9 \\
\hline 86 & 0 & 86 & +76 & 227 & 95 & 5 & 257 & 8 & 1 & 7 & 20 & 1 & 14 \\
\hline 83 & 0 & 83 & +6 & 178 & 101 & 5 & 278 & 11 & 1 & 7 & 20 & 1 & 14 \\
\hline 90 & 0 & 90 & +13 & 172 & 98 & 5 & 263 & 6 & 1 & 7 & 20 & 1 & 14 \\
\hline 90 & 0 & 90 & +13 & 159 & 111 & 5 & 277 & 4 & 1 & 7 & 20 & 1 & 14 \\
\hline 90 & 0 & 90 & +10 & 168 & 96 & 5 & 270 & 4 & 1 & 7 & 20 & 1 & 14 \\
\hline 95 & 0 & 95 & +10 & 209 & 92 & 5 & 321 & 3 & 1 & 7 & 20 & 1 & 14 \\
\hline 88 & 0 & 88 & $\mathbf{0}$ & 148 & 94 & 5 & 249 & 5 & 1 & 7 & 20 & 1 & 14 \\
\hline
\end{tabular}

$0.94 \pm 0.13 \mathrm{mEq}$ per $\mathrm{kg}$ per day in those of $\mathrm{Ta}-$ ble VI were not significantly different from the endogenous acid production in normal subjects not given alkali loads (Table II). Furthermore, as illustrated in Table III, there was no significant change in endogenous acid production in a given subject when a bicarbonate load was superimposed on the standard diet.

TABLE V

Acid balance in nine normal subjects given daily loads of $\mathrm{NaHCO}_{3}$ according to the "acute" and "recovery" protocols

\begin{tabular}{|c|c|c|c|c|c|c|c|c|c|}
\hline \multirow[b]{2}{*}{ Subject } & \multirow[b]{2}{*}{ Days } & \multirow{2}{*}{$\begin{array}{l}\text { Mean daily } \\
\text { endogenous } \\
\text { acid pro- } \\
\text { duction }\end{array}$} & \multirow{2}{*}{$\begin{array}{c}\text { Daily } \\
\mathrm{NaHCO}_{3} \\
\text { load }\end{array}$} & \multirow{2}{*}{$\begin{array}{l}\text { Mean } \\
\text { daily } \\
\text { net ef- } \\
\text { fective } \\
\text { acid pro- } \\
\text { duction }\end{array}$} & \multirow{2}{*}{$\begin{array}{c}\text { Mean } \\
\text { daily } \\
\text { net acid } \\
\text { excretion }\end{array}$} & \multirow{2}{*}{$\begin{array}{l}\text { Mean } \\
\text { daily } \\
\text { acid } \\
\text { balance }\end{array}$} & \multicolumn{3}{|c|}{ Serum $\mathrm{CO}_{2}$ content } \\
\hline & & & & & & & Initial & Final & Change \\
\hline "Acute" & & $m E q$ & $m E q$ & $m E q$ & $m E q$ & $m E q$ & \multicolumn{3}{|c|}{ mmoles $/ L$} \\
\hline P.R. & 9 & 50 & 160 & -110 & -90 & -20 & 29.4 & 28.0 & -1.4 \\
\hline R.J. & 7 & 67 & 150 & -83 & -49 & -34 & 29.1 & 28.1 & -1.0 \\
\hline C.P. & 8 & 64 & 150 & -86 & -68 & -18 & 31.0 & 31.7 & +0.7 \\
\hline B.M. & 8 & 80 & 150 & -70 & -66 & -4 & 20.9 & 30.9 & 0 \\
\hline G.N. & 8 & 57 & 140 & -83 & -62 & -21 & 34.2 & 33.8 & -0.4 \\
\hline \multicolumn{10}{|c|}{ "Recovery" } \\
\hline J.H. & 7 & 60 & 150 & -90 & -69 & -21 & 31.0 & 32.0 & +1.0 \\
\hline H.T. & 7 & 60 & 100 & -40 & -13 & -27 & 31.7 & 31.5 & -0.2 \\
\hline K.E.W. & 7 & 85 & 150 & -65 & -38 & -27 & 30.4 & 32.0 & +1.6 \\
\hline $\begin{array}{l}\text { R.R. } \\
\text { Mean of }\end{array}$ & 7 & 71 & 100 & -29 & -20 & -9 & 28.0 & 29.5 & +1.5 \\
\hline $\begin{array}{l}9 \text { studies } \\
\pm \mathrm{SD}\end{array}$ & & $\begin{array}{c}0.89 \pm .13 \\
\mathrm{mEq} / \mathrm{kg} / \text { day }\end{array}$ & & & & $-20 \pm 9$ & $30.6 \pm 1.8$ & $30.8 \pm 1.9$ & $+0.2 \pm 1.1$ \\
\hline
\end{tabular}


TABLE VI

Acid balance in four normal subjects given daily loads of $\mathrm{NaHCO}_{3}$ according to the "chronic" protocol

\begin{tabular}{|c|c|c|c|c|c|c|c|c|c|}
\hline \multirow[b]{2}{*}{ Subject } & \multirow[b]{2}{*}{ Days } & \multirow{2}{*}{$\begin{array}{l}\text { Mean daily } \\
\text { endogenous } \\
\text { acid pro- } \\
\text { duction }\end{array}$} & \multirow{2}{*}{$\begin{array}{c}\text { Daily } \\
\mathrm{NaHCO}_{3} \\
\text { load }\end{array}$} & \multirow{2}{*}{$\begin{array}{l}\text { Mean } \\
\text { daily net } \\
\text { effective } \\
\text { acid pro- } \\
\text { duction }\end{array}$} & \multirow{2}{*}{$\begin{array}{l}\text { Mean } \\
\text { daily } \\
\text { acid } \\
\text { excretion }\end{array}$} & \multirow{2}{*}{$\begin{array}{c}\text { Mean daily } \\
\text { acid } \\
\text { balance }\end{array}$} & \multicolumn{3}{|c|}{ Serum $\mathrm{CO}_{2}$ content } \\
\hline & & & & & & & Initial & Final & Change \\
\hline & & $m E \boldsymbol{q}$ & $m E q$ & $m E q$ & $m E q$ & $m E_{q}$ & & mmoles $/ L$ & \\
\hline B.M. & 6 & 83 & 150 & -67 & -64 & -3 & 33.3 & 31.8 & -1.5 \\
\hline R.J. & 6 & 68 & 150 & -82 & -53 & -29 & 28.1 & 28.6 & +0.5 \\
\hline J.S. & 8 & 69 & 150 & -81 & -49 & -32 & 30.2 & 30.9 & +0.7 \\
\hline $\begin{array}{l}\text { C.O. } \\
\text { Mean of } \\
4 \text { studies }\end{array}$ & 7 & $\begin{array}{c}97 \\
0.94 \pm 0.13\end{array}$ & 150 & -53 & -24 & -29 & 25.7 & 24.9 & -0.8 \\
\hline$\pm \mathrm{SD}$ & & $\mathrm{mEq} / \mathrm{kg} /$ day & & & & $-23 \pm 14$ & $29.3 \pm 3.3$ & $29.0 \pm 3.0$ & $-0.3 \pm 1.0$ \\
\hline
\end{tabular}

Effects of acid and alkali loads on balances of sodium, potassium, and chloride

Table VII summarizes the available data on the mean daily balance of acid, $\mathrm{Na}, \mathrm{K}$, and $\mathrm{Cl}$ in the studies reported in this paper and compares them with the data from 23 control studies on normal subjects. As would be expected from the unmeasured skin losses, sodium and chloride balances tended to be slightly positive in the control studies; the mean control potassium balance was very close to zero. The sodium balance was not significantly different in the $\mathrm{NH}_{4} \mathrm{Cl}$ studies, but was significantly more positive in the group given $\mathrm{NaHCO}_{3}$. Chloride balance was not significantly different in either experimental group, as compared to the control studies. Potassium balance was significantly more negative than control in the $\mathrm{NH}_{4} \mathrm{Cl}$ experiments and more positive than control in the studies with $\mathrm{NaHCO}_{3}$.

The last column in Table VII gives the mean values for the daily balance of $(\mathrm{Na}+\mathrm{K}-\mathrm{Cl})$. This derived datum is intended to give some estimate of the excess of univalent cation lost or retained during the period of study. Compared to the control group, subjects with $\mathrm{NH}_{4} \mathrm{Cl}$ acidosis were in significantly negative balance of $(\mathrm{Na}+$ $\mathrm{K}-\mathrm{Cl}$ ), whereas those given $\mathrm{NaHCO}_{3}$ loads seemed to retain excess cation.

In Figure 3, the mean daily balance of $(\mathrm{Na}+$ $\mathrm{K}-\mathrm{Cl}$ ) is plotted against the mean daily acid balance for each of the 41 studies summarized in Table VII. In addition, Figure 3 includes data from the recovery period following $\mathrm{NaHCO}_{3}$ loading in six subjects. The figure shows a sig-

TABLE VII

Mean daily balances of acid, sodium, potassium, and chloride in control experiments and during loading with $\mathrm{NH}_{4} \mathrm{Cl}$ or $\mathrm{NaHCO}_{3}{ }^{*}$

\begin{tabular}{cccccc}
\hline Group & Acid & $\mathrm{Na}$ & $\mathrm{K}$ & $\mathrm{Cl}$ & $(\mathrm{Na}+\mathrm{K}-\mathrm{Cl})$ \\
\hline $\begin{array}{c}\text { Normal controls } \\
(23) \dagger\end{array}$ & $0 \pm 7$ & $+8 \pm 14$ & $-2 \pm 9$ & $+14 \pm 14$ & $-8 \pm 13$ \\
$\begin{array}{c}\mathrm{NH}_{4} \mathrm{Cl} \text { to normal } \\
\text { subjects } \\
(5)\end{array}$ & $+24 \pm 9$ & $+4 \pm 15$ & $-12 \pm 10$ & $+21 \pm 14$ & $-30 \pm 15$ \\
$\begin{array}{c}\text { NaHCO } \\
\text { subjects normal } \\
(13)\end{array}$ & $\mathrm{p}<0.001$ & $\mathrm{p}>0.5$ & $\mathrm{p}<0.05$ & $\mathrm{p}<0.4 \cdot$ & $\mathrm{p}<0.025$ \\
& $-21 \pm 10$ & $+22 \pm 10$ & $+6 \pm 5$ & $+16 \pm 8$ & $+12 \pm 9$ \\
& $\mathrm{p}<0.001$ & $\mathrm{p}<0.025$ & $\mathrm{p}<0.01$ & $\mathrm{p}>0.5$ & $\mathrm{p}<0.001$
\end{tabular}

* All data given as mean \pm standard deviation. " $p$ " values refer to the difference between a given group and the normal controls.

$\dagger$ Number in parentheses refers to number of studies. 


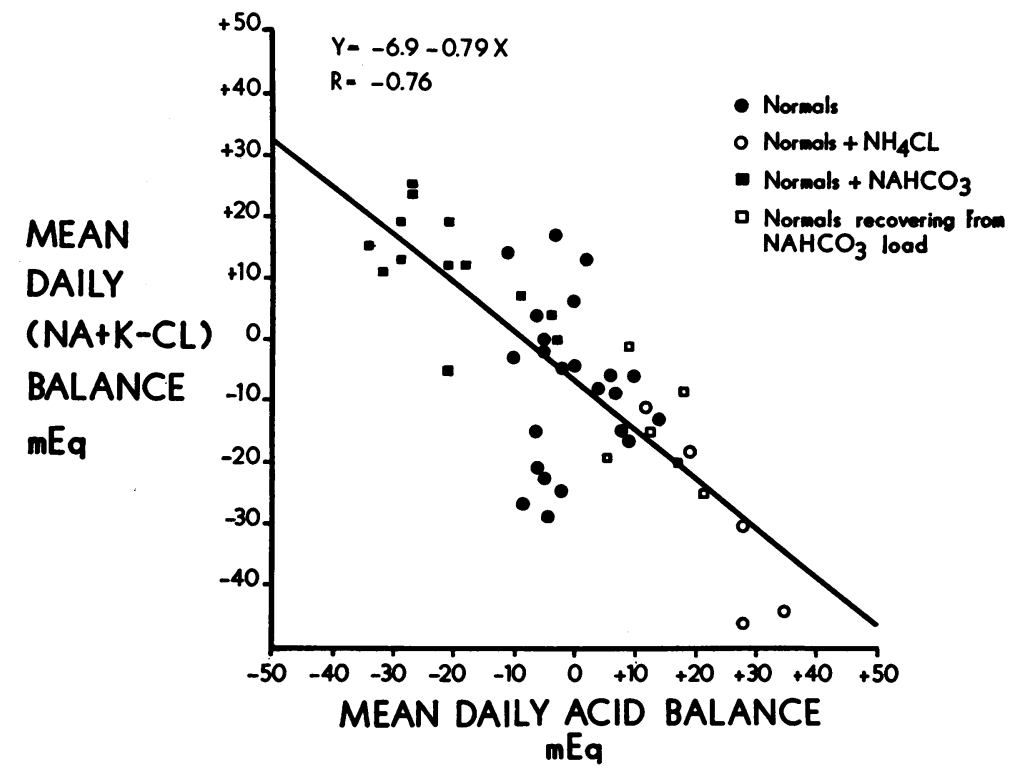

Fig. 3. Relation between mean daily balance of $\left(\mathrm{Na}_{\mathrm{A}}+\mathrm{K}-\mathrm{Cl}_{\mathrm{L}}\right.$ ) AND THE MEAN DAILY ACID BalaNCE IN THE 41 STUdies SUMMarized IN TABLE VII AND IN SIX OTHER STUDIES DURING RECOVERY FROM A LOAD OF $\mathrm{NAHCO}_{3}$.

nificant inverse relationship; the linear regression line of best fit (calculated by least squares) is : $y=-6.9-0.79 X$. The correlation coefficient is -.76. The data thus seem to suggest that retention or loss of acid was accompanied by a nearly equivalent inverse loss or retention of univalent cation.

\section{Discussion}

In the normal steady state, the rate of endogenous production of acid must be equal to the rate at which acid is removed from the body. When there is any significant difference between these two rates, the body buffer stores either take up or release acid. The major buffer in extracellular fluid is, of course, bicarbonate, and hence changes in extracellular buffer reserves are largely reflected by variations in serum bicarbonate concentration or $\mathrm{CO}_{2}$ content. Studies of the acute effects of large exogenous acid loads on the level of extracellular bicarbonate have demonstrated that the latter is in rapid equilibrium with another buffer pool of approximately equal capacity $(7,8)$. This second pool is presumably within cells and on the reactive surfaces of connective tissues and bone. Together with the extracellular bicarbonate, this pool constitutes what might be termed the "readily available" buffer stores of the body.
It is generally accepted that the urine is normally the major, if not the only, route of excretion of fixed metabolic acids from the body. This view was supported by previous studies from our laboratory in which it was demonstrated that the calculated endogenous production of metabolic acid under normal conditions was exactly balanced by the rate of excretion of acid in the urine (3). According to this view, therefore, it would be expected that whenever the addition of exogenous or endogenous acids to the body exceeded the rate of renal excretion of acid, the "readily available" buffer stores would be titrated, and hence the serum $\mathrm{CO}_{2}$ content would fall. Conversely, the serum $\mathrm{CO}_{2}$ content would be expected to rise whenever renal acid excretion exceeded the net production of acid.

In the preceding paper, it was shown that patients with chronic renal disease appear to be continuously retaining endogenous acid when they are acidotic, despite stable levels of serum $\mathrm{CO}_{2}$. The apparent retention of acid disappears when the acidosis is treated with bicarbonate, thus suggesting that acidosis per se stimulates some extrarenal mechanism that helps conserve the "readily available" buffer stores by disposing of the endogenous acid not excreted in the urine. The present 
studies demonstrate that the same mechanism seems to operate in normal subjects made severely acidotic with $\mathrm{NH}_{4} \mathrm{Cl}$. These experiments also indicate that when large alkali loads are fed to normal subjects, alkali seems to be continuously retained (or, in other terms, acid seems to be excreted in excess) without any detectable change in serum $\mathrm{CO}_{2}$ content and hence without any change in the state of the "readily available" buffers.

Unmeasured loss of acid or alkali in the stools might conceivably explain these results, but there is much reason to discount this possibility. In the first place, stools were very infrequent and scanty on the formula diet. Secondly, since renal acid excretion exactly balances acid production under normal conditions, it would be necessary to postulate that fecal excretion of acid or alkali is an adaptive function active only in the presence of excessive acid or alkali loads. There has never been any suggestion that the bowel is capable of such regulatory function. Furthermore, stool analyses in these experiments failed to reveal any systematic differences in the relation between fixed anions and cations that might indicate compensatory excretion of acid or alkali. The final, and to us the most cogent, argument against an important role of fecal excretion in the physiologic regulation of acid-base balance is the fact that renal adjustments in acid excretion seemed to account for the disposal of nearly all of the alkali loads in these experiments (Table IV); in other studies (9), it has also been shown that renal excretion accounts for virtually all of an exogenous load of acid.

To explain how acid might be continuously retained in the body without progressive depletion of the "readily available" buffer stores (as reflected by the serum $\mathrm{CO}_{2}$ content), it has been suggested elsewhere (2) that there is another relatively large store of buffer that is fixed in tissues and comes into play during chronic acidosis. If these fixed buffer stores had only limited contact with extracellular fluid, they would continue slowly to take up acid or release alkali in states of chronic acidosis, despite a constant serum $\mathrm{CO}_{2}$ content. Reasons were given in the preceding paper for proposing that bone would be a logical source of such buffer (2). The large diuresis of calcium and phosphorus that occurs during administration of $\mathrm{NH}_{4} \mathrm{Cl}$ in normal subjects lends some support to this suggestion as it applies to the present experiments, but it must be conceded that more work will be required to settle this question and to clarify the nature of the relationship between acid balance and the metabolism of calcium. The present studies were too brief in duration, and the stools were too few, to provide any meaningful data on the balances of calcium or phosphorus.

The observations on the acid balance in normal subjects given alkali loads seem to indicate that excess alkali can also be neutralized by fixed tissue buffers or else deposited in tissues so that it is not in equilibrium with the extracellular bicarbonate. The site and mechanism of this phenomenon are obscure at present, and there is no evidence to indicate whether bone is involved. The stimulus for the retention of alkali would not appear to be a significant rise in blood $\mathrm{pH}$ or serum $\mathrm{CO}_{2}$ because, as shown in Tables III, V, and $\mathrm{VI}$, tissue storage of alkali (or release of acid) occurs when blood $\mathrm{pH}$ and serum $\mathrm{CO}_{2}$ content are still within normal limits.

Tissue retention of acid was accompanied by a loss of univalent cation in excess of chloride, and retention of alkali was accompanied by a positive balance of cation (Table VII and Figure 3 ). This suggests that the retained acid was at least partly neutralized by an exchange of tissue cation with hydrogen ion. The data also suggest that the retained alkali was either stored as the sodium or potassium salt of bicarbonate (or of any other anion that is a potential source of bicarbonate), or neutralized by the exchange of tissue-bound hydrogen ions for sodium or potassium.

The hydrogen-univalent cation exchange in acidosis is probably important only in the initial phases, because it seems unlikely that chronically acidotic patients could sustain the requisite sodium and potassium losses for very long periods of time. Furthermore, there was no evidence of sodium or potassium losses in the balance studies of patients with chronic renal acidosis reported in the preceding paper (2). It seems more reasonable to account for the long-term retention of acid by the slow dissolution of bone, as previously discussed. How long retention of cation might continue in association with the retention of alkali 
loads is unknown. In the "chronic" experiments, there seemed to be no diminution in sodium retention after 4 to 7 weeks of continuous loading with alakali.

\section{Summary}

Normal subjects given large loads of $\mathrm{NH}_{4} \mathrm{Cl}$ were in continuously positive acid balance despite a low but stable serum $\mathrm{CO}_{2}$ content and blood $\mathrm{pH}$. Sustained administration of $\mathrm{NaHCO}_{3}$ to normal subjects caused a continuous retention of alkali (i.e., a negative balance of acid), although there was no progressive rise in serum $\mathrm{CO}_{2}$ content or blood $\mathrm{pH}$.

It has been suggested that slow dissolution of alkaline bone salts, stimulated by extracellular acidosis, could account for the apparent retention of chronic acid loads and that part of the initial response to sustained acidosis probably also involves exchange of hydrogen ions with sodium and potassium bound in tissues. The site and mechanism of the disposition of excess alkali are unknown. Retention of alkali was associated with nearly equivalent retention of univalent cation, suggesting either that this cation exchanged with hydrogen ions previously bound in tissues or that alkaline salts were deposited in tissues.

Regardless of their ultimate explanation, these observations demonstrate that excess acid or alkali can be continuously neutralized or stored in tissues without requiring the progressive titration of extracellular buffers.

\section{References}

1. Lemann, J., Jr., E. J. Lennon, A. D. Goodman, and A. S. Relman. The role of fixed tissue buffers in acid-base regulation. Trans. Ass. Amer. Phycns 1964,77 , in press.

2. Goodman, A. D., J. Lemann, Jr., E. J. Lennon, and A. S. Relman. Production, excretion, and net balance of fixed acid in patients with renal acidosis. J. clin. Invest. 1965, 44, 495.

3. Relman, A. S., E. J. Lennon, and J. Lemann, Jr. Endogenous production of fixed acid and the measurement of the net balance of acid in normal subjects. J. clin. Invest. 1961, 40, 1621.

4. Lennon, E. J., J. Lemann, Jr., and A. S. Relman. The effects of phosphoproteins on acid balance in normal subjects. J. clin. Invest. 1962, 41, 637.

5. Logsdon, E. E. A method for the determination of ammonia in biological materials on the autoanalyzer. Ann. N. Y. Acad. Sci. 1960, 87, 801.

6. Conway, E. J. Microdiffusion Analysis and Volumetric Error, rev. ed. London, Lockwood, 1947.

7. Swan, R. C., and R. F. Pitts. Neutralization of infused acid by nephrectomized dogs. J. clin. Invest. 1955, 34, 205.

8. Schwartz, W. B., K. J. Ørning, and R. Porter. The internal distribution of hydrogen ions with varying degrees of metabolic acidosis. J. clin. Invest. 1957, 36, 373.

9. Lemann, J., Jr., and A. S. Relman. The relation of sulfur metabolism to acid-base balance and electrolyte excretion: the effects of DL-methionine in normal man. J. clin. Invest. 1959, 38, 2215.

\section{SPECIAL NOTICE TO SUBSCRIBERS}

Post Offices will no longer forward the Journal when you move.

Please notify The Journal of Clinical Investigation, Business Office, 10 Stoughton Street, Boston, Mass. 02118, at once when you have a change of address, and do not omit the Zip Code number. 